\title{
Urea for SCR-Based NOx Control Systems and Potential Impacts to Ground Water Resources
}

\author{
D. Layton
}

January 3, 2002 


\section{DISCLAIMER}

This document was prepared as an account of work sponsored by an agency of the United States Government. Neither the United States Government nor the University of California nor any of their employees, makes any warranty, express or implied, or assumes any legal liability or responsibility for the accuracy, completeness, or usefulness of any information, apparatus, product, or process disclosed, or represents that its use would not infringe privately owned rights. Reference herein to any specific commercial product, process, or service by trade name, trademark, manufacturer, or otherwise, does not necessarily constitute or imply its endorsement, recommendation, or favoring by the United States Government or the University of California. The views and opinions of authors expressed herein do not necessarily state or reflect those of the United States Government or the University of California, and shall not be used for advertising or product endorsement purposes.

This work was performed under the auspices of the U. S. Department of Energy by the University of California, Lawrence Livermore National Laboratory under Contract No. W-7405-Eng-48.

This report has been reproduced directly from the best available copy.

Available electronically at http://www.doe.gov/bridge

Available for a processing fee to U.S. Department of Energy

and its contractors in paper from

U.S. Department of Energy

Office of Scientific and Technical Information

P.O. Box 62

Oak Ridge, TN 37831-0062

Telephone: (865) 576-8401

Facsimile: (865) 576-5728

E-mail: reports@adonis.osti.gov

Available for the sale to the public from

U.S. Department of Commerce

National Technical Information Service

5285 Port Royal Road

Springfield, VA 22161

Telephone: (800) 553-6847

Facsimile: (703) 605-6900

E-mail: orders@ntis.fedworld.gov

Online ordering: http://www.ntis.gov/ordering.htm

OR

Lawrence Livermore National Laboratory

Technical Information Department's Digital Library

http://www.llnl.gov/tid/Library.html 


\title{
Urea for SCR-based NOx Control Systems and Potential Impacts to Ground Water Resources
}

\author{
David Layton \\ Health and Ecological Assessment Division \\ Energy and Environment Directorate \\ Lawrence Livermore National Laboratory
}

One of the key challenges facing manufacturers of diesel engines for light- and heavy-duty vehicles is the development of technologies for controlling emissions of nitrogen oxides. In this regard, selective catalytic reduction (SCR) systems represent a control technology that can potentially achieve the NOx removal efficiencies required to meet new U.S. EPA standards. SCR systems rely on a bleed stream of urea solution into exhaust gases prior to catalytic reduction. While urea's role in this emission control technology is beneficial, in that it supports reduced NOx emissions, it can also be an environmental threat to ground water quality. This would occur if it is accidentally released to soils because once in that environmental medium, urea is subsequently converted to nitrate - which is regulated under the U.S. EPA's primary drinking water standards. Unfortunately, nitrate contamination of ground waters is already a significant problem across the U.S. Historically, the primary sources of nitrate in ground waters have been septic tanks and fertilizer applications. The basic concern over nitrate contamination is the potential health effects associated with drinking water containing elevated levels of nitrate. Specifically, consumption of nitrate-contaminated water can cause a blood disorder in infants known as methemoglobinemia.

The source of nitrate in effluents from septic tanks and associated leach lines is urea (i.e., $\left.\mathrm{CO}\left(\mathrm{NH}_{2}\right)_{2}\right)$ derived from human urine. Urea is a waste product of the metabolism of animal and plant protein in diets. It reacts rapidly with water to form ammonium, which subsequently undergoes bacterially-mediated oxidation to nitrate (i.e., $\mathrm{NH}_{4}{ }^{+}+2 \mathrm{O}_{2} \rightarrow \mathrm{NO}_{3}{ }^{-}+2 \mathrm{H}^{+}+\mathrm{H}_{2} \mathrm{O}$ ). The microbial nitrification of ammonium also occurs quickly and is often largely complete by the time the septic tank effluent has percolated through unsaturated soils to ground water. Concentrations of nitrate in those effluents, expressed as total $\mathrm{N}$, typically range from 30 to over $100 \mathrm{mg} \mathrm{N} / \mathrm{L}$. The drinking water standard for nitrate (measured as total $\mathrm{N}$ ) is $10 \mathrm{mg} / \mathrm{L}$. By comparison, a 32 wt.\% urea-deionized water blend for use in an onboard SCR control system (see Diesel Fuel News, 9/25/00) would contain $166 \mathrm{~g} \mathrm{~N} / \mathrm{L}$ ! What this means is that the storage tanks and dispensing systems for urea must be designed to prevent leaks that would contaminate soil/ground water resources. Nevertheless, leaking underground fuel tanks have been a persistent source of ground water contamination in urban areas throughout the U.S., and leak-free designs have yet to be achieved in practice. Important infrastructure issues to consider would be the comparative costs/benefits of subsurface vs. surface storage tanks for urea at diesel-fuel stations. Also, the concerns over possible ground water contamination will be greater in areas where water supply agencies rely on ground water for drinking water. Moreover, in locations where there is existing nitrate contamination, the threat of urea leaks from storage facilities will undoubtedly receive increased regulatory scrutiny. In the aftermath of the ground water contamination incidents associated with the fuel additive methyl tertiary butyl ether (MTBE) - an 
oxygenate meant to reduce automotive emissions - there is a much greater sensitivity among water purveyors nationwide of the environmental implications of fuel-related compounds.

There are other issues that should probably be dealt with in evaluating the role of urea for NOx reduction. For example, what are the lifecycle environmental impacts of urea, that is, the potential impacts associated with its synthesis from natural gas;

distribution via barge, tank cars, etc.; storage at dispensing sites; and finally end use in vehicles. Economic considerations would involve the costs of natural gas and deionized water plus any other additives that may be necessary to inhibit microbial oxidation in tanks. Work performed under the auspices of the U.S. Department of Energy by the University of California, Lawrence Livermore National Laboratory under contract No. W-7405-ENG-48. 